\title{
Uluslararası Spor Organizasyonlarında Gönüllü Motivasyonu ile Serbest Zaman Doyum Düzeyi Arasındaki İlişskinin İncelenmesi*
}

\author{
Batuhan ER ${ }^{1 \dagger}$ (D), Pmar GÜZEL GÜRBÜZ $Z^{2}$ \\ ${ }^{1}$ İstanbul Gedik Üniversitesi, Spor Bilimleri Fakültesi, İstanbul. \\ ${ }^{2}$ Manisa Celal Bayar Üniversi Üniversitesi, Spor Bilimleri Fakültesi, Manisa.
}

Orijinal Makale

Gönderi Tarihi: 31.03.2021
Kabul Tarihi: 13.05.2021
DOI:10.25307/jssr.906958

Online Yayın Tarihi: 30.06 .2021

Öz

Bu çalışmanın amacı; uluslararası spor organizasyonlarında görev alan gönüllülerin motivasyon faktörleri ile serbest zaman doyum düzeyleri arasındaki ilişkinin karşılaştırılması ve farklı demografik değişkenlere göre incelenmesidir. Araştırmanın örneklem grubunu ise, uluslararası spor organizasyonlarına katılan ve amaçlı örneklem yoluyla belirlenen; 99 kadın 168 erkek olmak üzere, toplam 267 (Ort yaş $\left._{2} 24.00 \pm 7.299\right)$ spor gönüllüsü bireyden oluşmaktadır. Araştırmada veri toplama amacıyla demografik bilgi formu, Uluslararası Spor Organizasyonları İçin Gönüllü Motivasyonları Ölçeği ve Serbest Zaman Doyum Ölçeği kısa formu kullanılmıştır. Elde edilen verilere tanımlayıcı istatistik, Bağımsız Örneklemler İçin T-Testi, Çok Değişkenli Varyans Analizi (MANOVA), Pearson Korelasyon ve Çoklu Doğrusal Regresyon analizleri uygulanmıştır. Analiz sonuçlarına göre uluslararası spor organizasyonlarında gönüllülük faaliyetlerine katılım gösteren bireylerin genel gönüllülük motivasyonu ile serbest zaman doyum düzeyleri arasında pozitif yönde, orta düzeyde ilişki tespit edilmiştir $(\mathrm{r}=.431, \mathrm{p}<.05)$. Çalışma sonuçları ve literatür ile birlikte, motivasyon ve serbest zaman yaklaşımları da göz önüne alındığında; uluslararası spor organizasyonlarında görev alan gönüllülerin serbest zaman doyumu ve motivasyon faktörleri arasında güçlü bir bağ olduğu ifade edilebileceği gibi yapılan bu çalışmanın literatüre önemli katkıları olacağı düşünülmektedir.

Anahtar kelimeler: Gönüllülük, Gönüllü Motivasyonu, Serbest Zaman Doyum, Uluslararası Spor Organizasyonları.

\section{Investigation of the Relationship Between Volunteer Motivation and Leisure Satisfaction in International Sports Organizations}

\begin{abstract}
The aim of this study is to compare the relationship between motivation factors and leisure time satisfaction levels of volunteers working in international sports organizations and their analysis according to different demographic variables. The sample group of the research was determined by the purposeful sampling who participated in the international sports organizations; It consists of 99 women and 168 men, totally 267 (Average $=24.00 \pm 7.299$ ) sports volunteers. Study data was collected via Demographic information form, Volunteer Motivations Scale for International Sports Organizations and Leisure Time Satisfaction Scale. Descriptive statistics, T-Test for Independent Samples, Multivariate Analysis of Variance (MANOVA), Pearson Correlation and Multiple Linear Regression analyzes were applied to the data obtained. According to the analysis results, a positive, moderate relationship was found between the general volunteering motivation and leisure time satisfaction levels of individuals participating in volunteering activities in international sports organizations $(\mathrm{r}=.431, \mathrm{p}<.05)$. Considering motivation and leisure time approaches together with the study results and literature; it can be stated that there is a strong connection between the leisure time satisfaction and motivation factors of volunteers working in international sports organizations, and it is thought that this study will contribute to the literature.
\end{abstract}

Keywords: Volunteerism, Volunteer Motivation, Leisure Satisfaction, International Sports Organizations.

\footnotetext{
* Bu makale, Batuhan ER'in Manisa Celal Bayar Üniversitesi Sosyal Bilimler Enstitüsü'nce kabul edilen "Uluslararası Spor Organizasyonlarında Gönüllü Motivasyonu ile Serbest Zaman Doyum Düzeyi Arasındaki İlişkinin İncelenmesi”” başlıklı Yüksek Lisans tezinden türetilmiştir.

† Sorumlu Yazar: Batuhan ER, E-posta: batuhaner32@hotmail.com
} 


\section{GíRiş}

Son yıllarda, ülkemizde ve dünyada önemi giderek artmakta olan spor etkinlikleri, bireylerin serbest zamanlarında, etkinliklerin bir parçası olabilmesi açısından fırsatlar sunmaktadır. Bununla birlikte uluslararası spor organizasyonları açısından bu durum, bireylerin gönüllü katılımcı olarak destekleri ile ev sahibi şehir ve ülkeler için önemli bir insan kaynağ1 oluşturmaktadır. Gönüllülerin katkısı, serbest zaman aktivitelerinin üretiminde de önemli bir girdidir. Bu durum büyük spor etkinliklerine ev sahipliği yapmak gibi çok çeşitli spor etkinlikleri için de geçerlidir. Planlama, organizasyon, pazarlama ve üretime yardımları genellikle yerel etkinlik organizatörleri için mali açık veya fazlalık arasındaki durumu belirlemektedir (Solberg, 2003). Uluslararası spor organizasyonları şehirler ve ülkeler açısından da farklı katkılar sağlayabilmektedir. Ev sahipliği durumunda, ülke ve şehirlere ulusal kültür ve kimliklerini sunma şansı adına küresel düzeyde bir araç olabilmektedir. Bununla birlikte organizasyonlar, geniş kitleler tarafından da yoğun ilgiyle takip edilmekte ve bu ilgi de toplum yaşamının standartlarının yükseltilmesi adına önemli firsatlar yaratmaktadır (Berber ve Terekli 2019). Serbest zamanın içerisinde oldukça önemli bir yere sahip olan gönüllülük kavramı dünyada birçok alanda popüler olmaya devam etmektedir. $\mathrm{Bu}$ alanlar gönüllü katkısı sağlanan etkinliklerin türlerine göre değişiklik gösterirken, gönüllülerin bu etkinliklere ekonomik, sosyal ve çevresel katkıları oldukça fazladır. Gönüllülüğün serbest zaman kavramıyla olan yakından ilişkisi içerisinde bireylerin, serbest zamanda gönüllü olarak bir etkinliğe katılması konusundaki doyumu ve motivasyon faktörleri önemli bir etkiye sahip olabilmektedir.

\section{Gönüllülük ve Serbest Zaman Kavramı İlişkisi}

2004 Dünya Serbest Zaman Kongresi'nde bir sunum "Gönüllü olmayan bir dünya hayal edebiliyor musunuz?" şeklinde bir soruyla başlamıştır (Cuskelly, Hoye ve Auld, 2006:2). Ringuet-Riot ve diğerleri de (2014) bu soruyu destekler nitelikte ancak belirli bir alana özgü vurgulama ile gönüllüler olmadan hiçbir spor sisteminin mümkün olamayacağını ve spor etkinliklerinin uygulanabilirliğini destekleyen kilit faktörün gönüllüler olduğunu ifade etmiştir. Gönüllülük toplumun vazgeçilmez bir öğesidir ve serbest zaman, spor, sağlık, eğitim ve sosyal olmak üzere birçok sektörde bireyler yaşlarına ve yaşam şartlarına göre çeşitli etkinliklerde gönüllü olabilirler (Downward ve Hallman, 2020). Sosyolojik anlamda gönüllülüğün serbest zaman olarak kavramsallaştırılmasına odaklanılırken, psikolojik bakış açısı gönüllülüğü güdüleyen motivasyonları anlamaya çalışmaktadır. Ekonomistler de bu bakış açılarını bireylerin gönüllü olma sebepleri açısından tamamlar ve gönüllülüğün katkılarını derinden incelemeye yönelim gösterirler (Lockstone-Binney, Holmes, Smith ve Baum, 2010).

Gönüllülük kavramı ve ciddi serbest zaman ile ilişkisi incelendiğinde ise; Van Til (1988) gönüllülüğün, bireyin kendisi tarafindan değer verdiği bir olaya doğrudan maddi kazanç sağlama amacı veya başkaları tarafından zorunlu tutulan bir baskı olmaksızın yardım eyleminde bulunması olarak tanımlanabileceğini belirtirken; Stebbins (1996) buna karşın, gönüllülük faaliyetleri ile ilgili olarak serbest zamanlarının azalması ve zorlayıcı unsurların artmasıyla birlikte, Van Til'in gönüllü tanımına uymalarının da aynı ölçüde zayıflayarak gönüllülüğün yaşlı ve işsiz bireyler için bir tür meşguliyet, genç bireyler için ise bir iş bulma stratejisi olarak zorlanma hissine de sahip olabileceğini belirtmiştir. Parker (1997) ise bireyin 
değerli olduğuna inanılan bir nedene kendini özgürce verebileceğini ve kolektif bir serbest zaman deneyimi olarak serbest zamanlarda yardımlaşma ya da bir şeyler üretme amaciyla da toplulukla birlikte gönüllü olabileceğini belirtmiştir. Gallant ve diğerleri de (2013) gönüllülüğe bireysel katılımın da mümkün olduğunu ancak çoğu bireyin kulüpler, dernekler, resmi olmayan gruplar, ticari mekanlar ve etkinlikler aracılığı ile gönüllülük faaliyetlerine katılım sağlayarak sosyal ilişki arayışında olabileceğini vurgulamıştır.

Günümüzde gönüllülük, Stebbins'in uzun yıllar süren çalışmalarında da belirtildiği üzere "Ciddi Serbest Zaman Perspektifinin” bir parçası olarak tanımlanabilmektedir. Sürekli bir şekilde gönüllü çalışmalarına katılım, bireyin bağlılığını gerektirmektedir (Cuskelly, Harrington ve Stebbins, 2002). Bireyler birçok nedenden dolayı gönüllü olmaya motive olurlarken, çoğu birey için bu durum bir serbest zaman seçimi olarak ifade edilmektedir (Ringuet, 2012).

\section{Ciddi Serbest Zaman Perspektifi ve Serbest Zaman Doyumu}

Serbest zamana katılım ve bu katılımdan elde edilen doyum boyutunun ilişkilendirildiğgi yaklaşım olan ciddi serbest zaman perspektifinin, gönüllü bireylerin serbest zamanlarında faaliyetlere katılım davranışının açıklanmasına katkıda bulunabileceği düşünülmektedir. "Ciddi Serbest" Zaman kavramı sosyal bilim çevresinde ortaya çıkan; katılımcıları için önemli ve ilginç olabilen, bununla birlikte beceri, bilgi ve deneyimlerine katkıda bulunabilen amatör, hobi veya gönüllü bir faaliyetin sistematik olarak takip edilmesini ifade eden bir yaklaşımdır (Stebbins, 2006:448). "Ciddi Serbest Zaman Perspektifi" ifadesi, ciddi serbest zaman, kayıtsız serbest zaman ve proje tabanlı serbest zaman olarak bilinen üç temel serbest zaman biçimini sentezleyen teorik çerçevenin adıdır (Stebbins, 2007:1).

Yaklaşım içerisindeki serbest zaman türlerinden biri olan "proje tabanlı serbest zaman" etkinliklerini üstlenme motivasyonunun, diğer serbest zaman biçimleri gibi organizasyonel bir temele sahip olabileceği ifade edilmiştir. Stebbins'e göre küçük gruplar, taban dernekler (düşük ücretli veya ücretsiz gönüllü olan gruplar) ve gönüllü kuruluşların (gönüllü yardım kullanan ücretli personel grupları), bireylerin proje tabanlı serbest zaman etkinliklerini üstlendiği en yaygın kuruluş türleri olduğunu göstermektedir (Stebbins, 2005; 2016:34). Ayrıca proje tabanlı serbest zamanın bir spor etkinliği için gönüllü olarak bireysel katılımcıyı örgütsel bir ortama çekebildiği ifade edilmiştir (Stebbins, 2016:35).

Ciddi Serbest Zaman Perspektifi'nde belirtilen proje temelli serbest zamanın bir defalık proje türleri yapım uğraş, serbest sanatlar, aktivite katılımı, gönüllük ve sanat projeleri olarak sınıflandırılmıştır. Bu sınıflamada gönüllülük boyutu ise; yerel, ulusal veya uluslararası kapsamda bir kongre veya konferansta gönüllü olmak, yerel, ulusal veya uluslararası bir spor yarışmasında gönüllü olmak, bir sanat festivalinde ya da müzede özel bir sergide gönüllü olmak, kasırga, deprem, petrol sızıntısı veya endüstriyel kaza nedeniyle meydana gelen doğal veya insan kaynaklı bir felaketten sonra insan hayatını veya vahşi yaşamı iyileştirmeye yardımcı olmak için gönüllü olma şeklinde sınıflandırılmıştır (Stebbins, 2005; 2014:26; 2016:36). 
Proje tabanlı serbest zaman, ciddi serbest zamanda yaşanan birçok ödülü de üretebilmektedir. Ayrıca ciddi serbest zamanlarda olduğu gibi, proje temelli serbest zamanlarda da bu ödüller tatmin edici bir faaliyetin sürdürülmesi için motivasyon temelinin bir parçasını oluşturabilmektedir (Stebbins, 2005; 2016:34).

Çalışmanın serbest zaman doyumu boyutunun ciddi serbest zaman yaklaşımı ile ilişkisi incelendiğinde; Lu ve Argyle (1994) bireylerin ciddi serbest zaman etkinliklerine katılım gösterdiklerinde serbest zaman doyum ve mutluluk düzeylerinin arttığını belirtmiştir. Liu (2014) ciddi serbest zaman etkinliklerine katılan bireylerin, katılmayan bireylere göre serbest zaman doyum ve öznel iyi olma halinin daha yüksek olduğunu ifade etmiştir. Yine Liu ve Yu (2015) ciddi serbest zaman katılımcilarının, serbest zaman doyumu ve genel serbest zaman doyumunda ciddi olmayan serbest zaman katılımcılarına göre önemli ölçüde daha yüksek olduğunu ifade etmişlerdir.

Tian ve diğerleri (2020) çalışmasında ciddi serbest zamanın, serbest zaman doyumu ve öznel iyi olma hali ile ilişkili olduğunu belirtmişlerdir. Cheng (2010) ise ciddi serbest zaman yaklaşımı ve öz belirleme kuramı ile ilişkili çalışmasında; yaşlı bireyler tarafından gerçekleştirilen serbest zaman bahçe işleri etkinliklerinde, ciddi serbest zaman yaklaşımını araştırmayı ve uygulamayı amaçlamış; bu sürecin bir parçası olarak ise bahçe işlerine katılımdan kaynaklanan motivasyon ve doyumlarının yanı sıra, bu serbest zaman arayışına bağlı yaşlı bireylerin anlam ve değerlerini tespit etmeye çalışmıştır.

\section{Öz-Belirleme Kuramı ve Gönüllü Motivasyonu}

Çalışmanın gönüllü motivasyonu boyutunun ilişkilendirildiği teorik çerçeveyi oluşturan yaklaşım olan Öz-Belirleme Kuramı ve bu kuramın, Bilişsel Değerlendirme ve Organizmik Bütünleşme olarak adlandırılan alt kuramları ile gönüllü katılımcıların davranışlarındaki içsel ve dışsal motivasyon süreçlerinin açıklanmasına 1şık tutabileceği düşünülmektedir.

Öz-Belirleme (Özerklik) Kuramı, insan motivasyonu, kişilik gelişimi ve iyi olma halini içeren bir makro kuramdır. Kuram özellikle bireyin istemli ya da kendi belirlediği davranışlara ve onu teşvik eden sosyal, kültürel koşullara odaklanmaktadır (Ryan, 2009). Öz-belirleme kuramının geliştirilmesinde Deci ve Ryan, temel motivasyon kavramlarını ve temel psikolojik ihtiyaçları, her biri motivasyon teorisinin farklı problemlerini ele alan altı mini kuram içine dahil etmişlerdir. Bu mini kuramlar birlikte öz-belirleme kuramının işleyişini açıklamaktadır. $\mathrm{Bu}$ mini kuramlar Bilişsel Değerlendirme Kuramı, Organizmik Bütünleşme Kuramı, Nedensellik Yönelimi Kuramı, Temel Psikolojik İhtiyaçlar Kuramı, Hedef İçerik Kuramı ve İlişkiler Motivasyon Kuramı'dır (Adams, Little ve Ryan 2017).

Bireylerin kendi davranışlarını başlatmalarında ve düzenlenmelerinde seçim duygusunu yaşamaları öz-belirleme olarak tanımlanmıştır. Öz Belirleme Kuramı ise, kişilik gelişimi ve davranışsal öz-düzenleme için bireylerin gelişen iç kaynaklarının önemini vurgulayan bir organizma meta teorisi kullanırken, deneysel yöntemleri kullanan insan motivasyonu ve kişiliğine bir yaklaşımdır (Ryan ve Deci, 2000). Deci ve Ryan motivasyonun üç belirleyicisi olduğunu belirtmiştir ve bunlar; özerklik, yeterlik ve ilişkili olmadır. Öz Belirleme Kuramı insan motivasyonunun anlaşılmasının, yeterlilik, özerklik ve ilişkili olma gibi doğuştan gelen 
psikolojik ihtiyaçların göz önünde bulundurulmasını gerektirdiğini savunur (Deci ve Ryan 2000). Deci ve Ryan Öz-Belirleme Kuramı'nın amacını, bireylerin, grupların, toplumların sağlıklı bir biçimde gelişmesini sağlayan koşulları belirlemek ve büyüme, bütünleşme, iyi olma sürecinde etkin olan faktörleri net bir biçimde tanımlamak olarak ifade etmişlerdir (Aktaran: Çankaya, 2009).

Oostlander ve diğerleri (2014) gönüllü motivasyonunu inceleme amacıyla yaptığı çalışmada teorik çerçeve olarak Öz-Belirleme Kuramından yararlanmış ve çalışmada bireysel farkl1lıkların gönüllü motivasyonu üzerindeki düzenleyici rolünün önemini tartışıştır. Güntert ve diğerleri (2016) de Öz-Belirleme Kuramı perspektifinden gönüllülerin motivasyonlarının sistematik olarak öz-belirlendiği veya kontrollü motivasyon türleri ile ilişkilendirilebileceğini ifade etmiştir. Wu ve diğerleri (2016) Öz-Belirleme Kuramını kullanarak yeterlilik, içsel motivasyon, iş tatmini ve gönüllülüğe devam etme niyeti arasındaki ilişkiyi test etmek amacıyla bir çalışma gerçekleştirmiştir. Bununla birlikte Öz-Belirleme Kuramının gönüllüğü sürdürme niyetini anlamada yararlı bir teorik çerçeve olduğunu ifade etmişlerdir.

\section{Gönüllü Motivasyonu ve Serbest Zaman Doyumu}

Gönüllü motivasyonu Lee ve diğerleri (2014) tarafindan; bireylerin gönüllü firsatları arama, gönüllü yardım etmeye kendini adama ve gönüllülüğe katılımlarını uzun süreler boyunca sürdürme güdüsü olarak tanımlanmıştır. Yine aynı çalışmada belirtildiği üzere gönüllü doyumunun; gönüllülük için harcanan zamanın, gönüllülük hizmetinin uzun vadedeki durumunun ve gönüllülüğe devam etme niyetinin bir göstergesi olduğunu olduğu ileri sürülmüștür. Çalışmada gönüllü doyumunu, gönüllü motivasyonunun bir sonucu olarak, gelecekteki gönüllülük kararlarının bir yordayıcısı olarak kabul edilmiştir.

Serbest zaman doyumu ise bireyin serbest zaman aktivitelerine katılımı sonucu ortaya çıkan veya kazandığı, olumlu algı ya da duygular olarak tanımlanabilir. Diğer bir deyişle serbest zaman deneyimlerinden memnun olma derecesi olarak ifade edilebilir (Beard ve Ragheb, 1980). Ardahan ve Yerlisu Lapa da (2010) serbest zaman doyumunu; bireylerin dişsal zorlamalara bağlı kalmaksızın, yeni beceriler kazanma, sağlık, yenilenme, eğlenme ve mutluluk duygusu elde etme gibi amaçlarla, gönüllü olarak, herhangi bir maddi kazanç beklentisi olmaksızın aktif ya da pasif olarak katıldığı etkinliklerden beklentilerinin karşılanma derecesi olarak ifade etmişlerdir.

Cnaan ve Goldberg (1991) sosyal hizmetlerden 258 gönüllü ve 108 gönüllü olmayan bireyin karşılaştırma amacıyla bulunduğu örneklem grubu ile bir çalışma gerçekleştirmiştir. Çalışma, literatürdeki çalışmalardan içerik analizi yoluyla uyarlanmış 28 maddelik "Gönüllü Motivasyonu Ölçeğì” ile yürütülmüştür. Farrell ve diğerleri (1998) Mart 1996'da Kanadalı Kadınlar Curling Şampiyonası'nda 300 gönüllüden oluşan bir örneklem grubuyla gönüllü motivasyonu üzerine çalışmayı amaçlamışlar. Çalışmada kullanılan Özel Etkinlik Gönüllü Motivasyonu ölçeği ile gönüllü motivasyonunu 4 farklı boyutta olmak üzere; amaca yönelik, dayanışma, dış gelenek ve bağlılık olarak incelemişlerdir. Clary ve diğerleri (1998) gönüllü motivasyonu faktörlerini işlevsel analiz teorisi ile ele almıştır. Buna göre araştırma, bireyleri eyleme geçiren süreçlerin (eylemi başlatan, yönlendiren ve sürdüren) anlaşılarak motivasyonel 
araştırmanın temel kaygıları olan "insanlar neden gönüllü oluyor?" ve "gönüllü yardımı sağlayan nedir?" sorularını ele almaktadır. Twynam ve diğerleri (2002) tarafından yapılan çalışmada, 1998 Star Choice World Junior Curling Cup Turnuvası'nda görev yapan 190 gönüllü çalışmanın örneklem grubunu oluşturmaktadır. Khoo ve Engelhorn (2007) tarafından yapılan bir başka çalışmada ise Haziran 2006'da Malezya'nın Kuala Lumpur kentinde düzenlenen 13. Malezya Paralimpiad'daki (iki yılda bir engelli sporcular için düzenlenen ulusal spor yarışması) gönüllülerin motivasyonlarını araştırmışlardır. Çalışmanın örneklem grubunu iki farklı devlet üniversitesinde öğrenci olan 301 gönüllü oluşturmuştur. Giannoulakis ve diğerleri (2008) tarafından yapılan araştırmanın hedef kitlesini 2004 Atina Olimpiyat Oyunları'nda görev alan gönüllüler oluşturmuştur. Çalışmanın örneklem grubunu oluşturan 146 katılımcıya Olimpik Gönüllü Motivasyon Ölçeği uygulanmıştır. Bu ölçek ile "Olimpiyatla İlgili”, "Egoistik (Bencil)" ve "Amaca Yönelik” motivasyon faktörleri incelenmiştir. Bang ve Chelladurai (2009) uluslararası spor organizasyonlarına katılım gösteren gönüllülerin motivasyon faktörlerinin belirlenmesi amacıyla, önce 2002 FIFA Dünya Kupası'nda 509, daha sonra 2002 Asya Oyunları'nda 632 gönüllü ile yaptıkları çalışmalar sonucunda Uluslararası Spor Organizasyonları İçin Gönüllü Motivasyonları Ölçeği’ni geliştirmişlerdir. Ölçeğin spesifik olarak uluslararası spor organizasyonlarındaki gönüllü motivasyonunu incelemek üzere geliştirilmiş olması çalışmanın önemini ortaya koymaktadır. Bang ve diğerleri (2009) ise ölçeğin revize çalışmasını 2004 Atina Olimpiyat Oyunları'nda görev alan 206 gönüllü ile gerçekleştirmişlerdir. Bang ve Ross (2009) ise Uluslararası Spor Organizasyonları İçin Gönüllü Motivasyonları Ölçeği'nin revize edilmiş biçimde kullanarak gönüllülerin motivasyon faktörleri ile gönüllü doyum düzeyleri arasındaki ilişkiyi incelemişlerdir. Veriler 2004 Twin Cities Maratonu için gönüllü olan 254 katılımcıdan toplanmıştır. Wang ve Yu (2015) 2010 Şangay Expo Fuarı'nda 579 üniversite öğrencisinin oluşturduğu örneklem grubu ile bir çalışma gerçekleştirmişlerdir. Çalışmanın temel amacı, üniversite öğrencisi gönüllülerin güdülerini ve algılanan psikolojik sözleşme durumunu araştırarak, özel etkinlikler için uzun süreli gönüllülüğün yordayıcılarını belirmek olarak ifade edilmiştir. Çok boyutlu gönüllü motivasyon ve psikolojik sözleşme kavramını benimseyen çalışma, 2010 Şangay Expo Fuarı ile ögrenci uzun süreli gönüllülüğünü ve gönüllülük için davranışsal amaçlarını eş zamanlı olarak araştırmayı hedeflemiştir. Fişne ve Karagöz (2016) ise uluslararası spor organizasyonlarında görev alan gönüllülerin motivasyonel faktörlerini belirlenmesi ve bununla birlikte Bang ve diğerleri (2009) tarafından geliştirilen Uluslararası Spor Organizasyonları için Gönüllü Motivasyonları Ölçeği'nin; Türkçe’ye uyarlanması, geçerlik ve güvenirliğinin sınanması amacıyla bir çalışma gerçekleştirmişlerdir. Araştırmanın çalışma grubunu, 2013 yılında Türkiye'de gerçekleştirilen uluslararası spor organizasyonlarından FIFA U-20 Dünya Kupası'nda görev alan 109 gönüllü ile Akdeniz Oyunları'nda görev alan 223 gönüllü olmak üzere toplam 332 gönüllü oluşturmuştur.

Beard ve Ragheb (1980) serbest zaman doyumu kavramını inceleme, açıklama ve ölçme ile ilgili bir aracın gelişim ve yeterliliğini tanımlama amacıyla bir çalışma gerçekleştirmiştir. Bu çalışma sonucunda Serbest Zaman Doyumu Ölçeği uzun formu ortaya çıkmıştır. Kaufman (1988) ise serbest zaman doyumu, serbest zamana katılım ve kaygı düzeyi arasındaki ilişkiyi inleme amacıyla, Amerikan Emekli Bireyler Derneği katılımcıları ile bir çalışma gerçekleştirmiştir. Brown ve Frankel (1993) serbest zaman fiziksel aktivite katılımını, serbest zaman doyumu ve yaşam doyumu perspektifinden incelemişlerdir. Broughton ve Beggs (2007) ise yaşlı bireylerin serbest zaman doyumundaki farklılıkları çeşitli değişkenlere göre 
incelemişlerdir. Karlı ve diğerleri (2008) ise Beard ve Ragheb (1980) tarafından geliştirilmiş olan Serbest Zaman Doyum Ölçeği'nin üniversite öğrencileri için geçerlik ve güvenilirliğini tespit etme amacıyla bir çalışma gerçekleştirmişler ve Serbest Zaman Tatmin Ölçeği olarak uygulamışlardır. Yine Gökçe ve Orhan (2011) Beard ve Ragheb (1980) tarafindan geliştirilen (uzun form) ve 1992 y1lında kısa form olarak yeniden düzenlenen Serbest Zaman Doyum Ölçeği'nin kısa formunun Türkçe dil geçerlik ve güvenirliğinin yapılması amacıyla bir çalışma gerçekleştirmiş̧lerdir. Yerlisu Lapa (2013) rekreasyonel aktivitelere katılan bireylerin yaşam doyumu, serbest zaman doyumu ve algılanan özgürlükleri arasındaki ilişkiyi belirlemek ve serbest zaman doyumu ile algılanan özgürlüğü belirli değişkenlere göre karşılaştırma amacıyla rekreasyon amaçlı spor aktivitelerine katılım gösteren 397 birey ile bir çalışma gerçekleştirmiş̧ir. Shin ve You (2013) 3188 ergenlik dönemindeki bireyden oluşan bir örneklem grubu ile, serbest zaman türünün serbest zaman doyumu üzerindeki etkisini ve bunun ergenlik dönemindeki bireylerin psikolojik iyi olma hali üzerindeki etkilerini incelemiştir. Mouratidis (2019) ise belirli bir bölgede toplanan anket, görüşme ve mekânsal verilere dayanan ve nitel analiz ile birlikte yapısal eşitlik modellemesini kullanan bir çalışmayı, çevre ile serbest zaman doyumu arasındaki nedensel yolların incelenmesi açısından doğrudan, dolaylı ve toplam etkiler üzerine gerçekleştirmişlerdir.

Literatürde gönüllülerin motivasyon ve gönüllü doyumu boyutları ile ilgili yapılan bazı çalışmalar Farrell ve diğerleri (1998) Bang ve Ross (2009) Lee ve diğerleri (2014) mevcut olmasına karşın; ciddi serbest zaman katılımı olarak değerlendirilen spor organizasyonlarına gönüllü katılım ve bu gönüllü katılım ile ilişkili olarak serbest zaman doyumu ile ilgili spesifik olarak herhangi bir çalışma bulunmadığı ifade edilebilir. Sonuç olarak uluslararası spor organizasyonlarında görev alan gönüllülerin motivasyon ve serbest zaman doyumu boyutları arasındaki ilişkinin açıklanabilmesi açısından böyle bir çalışma yapılması ihtiyacı ortaya çıkmış olup, bu öznel yönün literatüre önemli katkıları olacağı düşünülmektedir.

$\mathrm{Bu}$ çalışmadaki temel amaç; uluslararası spor organizasyonlarında görev alan gönüllülerin motivasyon faktörleri ile serbest zaman doyum düzeyleri arasındaki ilişkinin karşılaştırılması ve farklı demografik değişkenlere göre incelenmesidir. Bu kapsamda, uluslararası spor organizasyonlarında görev alan gönüllü katılımcıların, motivasyon ve serbest zaman doyum faktörlerinde, cinsiyet değişkenine göre farklar; cinsiyet ve sporla ilgilenim değişkenlerinin gönüllü motivasyonu ve serbest zaman doyum düzeylerine etkisi; gönüllülü̈k motivasyonunun, serbest zaman doyum düzeyine etkisinin incelenmesi çalışmanın alt amaçları olarak belirlenmiş̧tir.

\section{YÖNTEM}

\section{Araştırma Modeli}

$\mathrm{Bu}$ araştırmada, ölçümler yoluyla elde edilen ve analize uygun sayıların çalışılmasını ifade eden nicel araştırma (Sayım, 2015:27) yöntemlerinden "betimsel ve ilişkisel tarama modeli" kullanılmıştır. 


\section{Çalışma Grubu}

Çalışma grubu, ülkemizde gerçekleştirilen 25. Balkan Salon Atletizm Şampiyonası, Vodafone 41. İstanbul Maratonu, UEFA Süper Kupa 2019 Finali ve Samsung 31. Boğaziçi Kıtalararas1 Yüzme Yarışı uluslararası spor organizasyonlarına katılan ve amaçlı örneklem yoluyla belirlenen; 99 kadın 168 erkek olmak üzere, toplam 267 (Ortyaş $=24.00 \pm 7.299$ ) spor gönüllüsü bireyden oluşmaktadır. Amaçlı örneklem yönteminin seçilme nedeni aynı zaman dilimi içerisinde incelenen tüm uluslararası spor organizasyonların niteliği ve bu organizasyonlara gönüllülerin katılım yoğunluğudur. Çalışmada; araştırmanın amacına uygun olması sebebiyle, araştırmacının önceki bilgi, deneyim ve gözlemlerini de dikkate alarak, örnekleme dâhil edilecek birimlerin belirlenmesini sağlayan "amaçlı örnekleme yöntemi” tercih edilmiştir (Ural ve Kilıç, 2018:40).

\section{Veri Toplama Araçları}

Araştırmada veri toplama aracı olarak, araştırmacı tarafından hazırlanan kişisel bilgi formu, Fişne ve Karagöz (2016) tarafından Türkçe uyarlaması yapılan "Uluslararası Spor Organizasyonları İçin Gönüllü Motivasyonları Ölçeği” ile Gökçe ve Orhan (2011) tarafından Türkçe uyarlaması yapılan “Serbest Zaman Doyum Ölçeği” kullanılmıştır.

Uluslararası Spor Organizasyonları İçin Gönüllü Motivasyonları Ölçeği: Veri toplama araçlarından biri olarak kullanılan Uluslararası Spor Organizasyonları İçin Gönüllü Motivasyonları Ölçeği, ilk olarak Bang ve diğ. (2009) tarafindan uluslararası spor organizasyonlarında görev alan gönüllülerin motivasyonel faktörlerini incelemeye yönelik olarak geliştirilmiştir. Ölçek, 30 madde ve 7 boyuttan oluşmaktadır ve 7'li Likert tipine sahiptir. Bununla birlikte ölçeğin alt boyutları; "değerlerin ifadesi", "vatanseverlik", "kişilerarası ilişkiler", "kariyer yönlendirme", "kişisel gelişim”, “dışsal ödüller” ve "spor sevgisi” şeklindedir. Fişne ve Karagöz (2016) tarafından Türkçe geçerliliği ve güvenilirliği test edilen ölçekte, özgün ölçekte bulunan "kişisel gelişim” faktörünün 4 maddesinin tamamı ile “değerlerin ifadesi” faktöründen bir madde çıkarılmıştır. Bununla birlikte ölçeğin son hali; 7'li Likert tipi (1=hiç katılmıyorum, 7=tamamen katılıyorum) 25 madde ve 6 alt boyuttan oluşmaktadir.

Serbest Zaman Doyum Ölçeği: Serbest Zaman Doyum Ölçeği uzun formu Beard ve Ragheb (1980) tarafından geliştirilmiş olup, şimdi kullanılmakta olan kısa form, uzun formun yerine 2002 yılında Idyll Arbor, Inc tarafından düzenlenmiştir. Toplam 24 maddeden oluşan ölçek 5'li Likert tipine sahiptir. Türkçe geçerlilik ve güvenilirliği Gökçe ve Orhan (2011) tarafindan yapılan Serbest Zaman Doyum Ölçeği yine 24 madde ve 6 alt boyuttan oluşmakta olup, 5'li Likert tipi ( $1=$ neredeyse hiç doğru değil, $5=$ =neredeyse her zaman doğru) ölçek yapısına sahiptir. Ölçeğin alt boyutları; "psikolojik", "eğitimsel", "sosyal”, "rahatlama", "fizyolojik" ve "estetik" şeklindedir.

Araştırma Yayın Etiği: Bu çalışmanın etik onamı, Manisa Celal Bayar Üniversitesi Sosyal ve Beşeri Bilimler Bilimsel Araştırma ve Yayın Etiği Kurulu'nun 02.01.2020 tarihli toplantısında ve 050.01.04 sayılı kararı ile alınmıştır. 
Tablo 1. Ölçeklere ilişkin güvenilirlik, KMO ve Bartlett küresellik test sonuçları

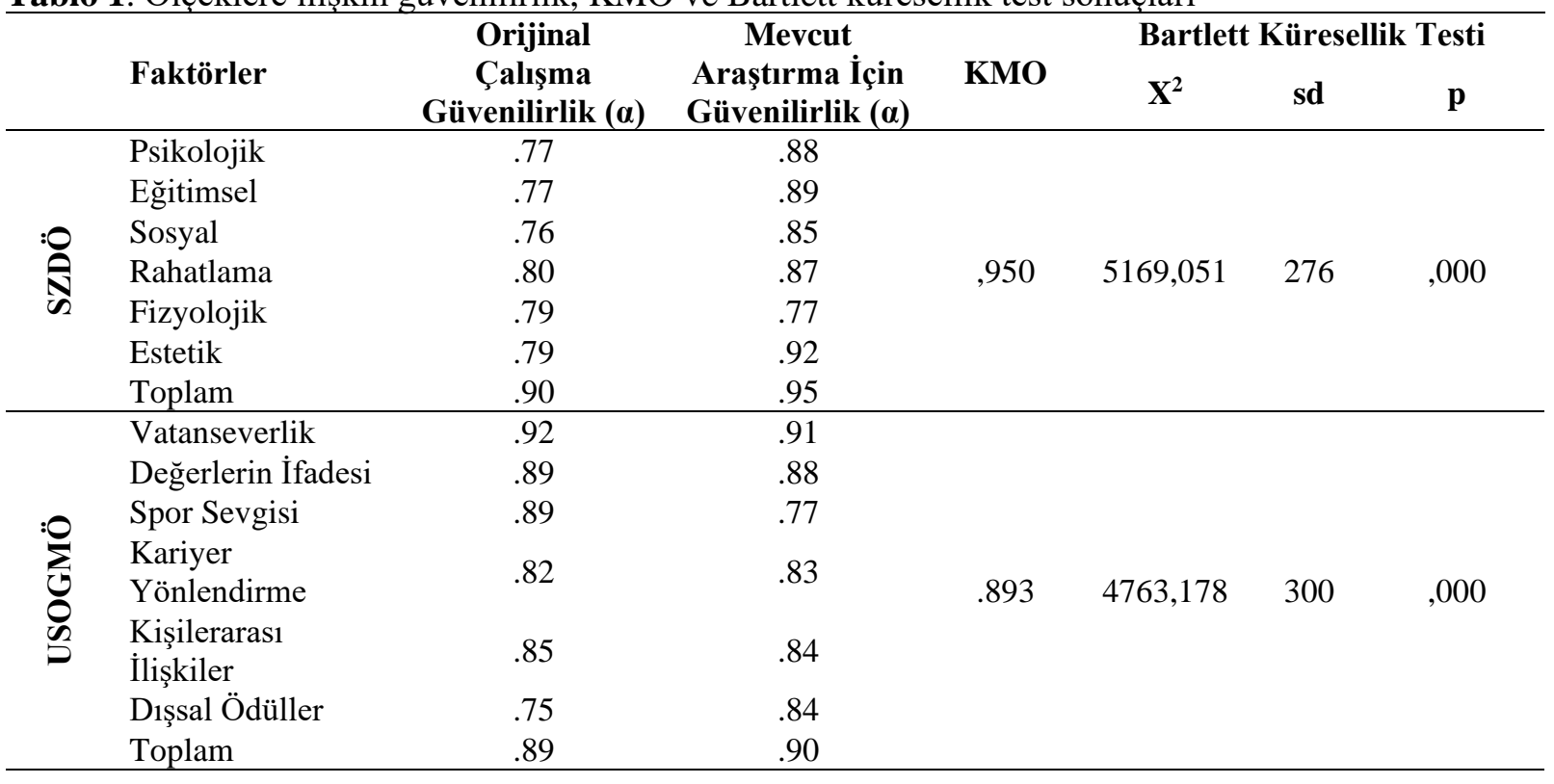

\section{Verilerin Toplanması}

Araştırma öncesi Gençlik ve Spor Gönüllüleri Derneği’nden gerekli resmi izin alınarak, hedef kitle olan uluslararası spor organizasyonlarında gönüllülük faaliyetlerine katılım gösteren bireylere araştırmanın amacı hakkında bilgiler verilmiştir. Veri toplama araçları olan ölçekler ve demografik bilgi formu ile birlikte Ocak-2020 ile Mart-2020 tarihleri arasında yüz yüze uygulanmış ve geçmiş organizasyonlara yönelik gönüllü katılımları da dahil edilmiştir. Verilerin toplanması sırasında, gönüllü katılımcılara ölçeklerle ilgili de gerekli detaylı bilgiler verilmiştir.

\section{Verilerin Analizi}

Verilerin analizinde SPSS 25.0 paket programı kullanılmıştır. Verilerin istatiksel gösterimlerinde aritmetik ortalama, standart sapma ve frekans değerleri sunulmuştur. Örneklem yeterliliği için KMO ve Bartlett Küresellik Testi uygulanmıştır. Merkezi limit teoremi çerçevesinde örneklem sayılarının oldukça makul olması sebebiyle doğrudan parametrik test istatistiklerinden yararlanılmıştır. Bu kapsamda Bağımsız Örneklemler İçin TTesti, Çok Değişkenli Varyans Analizi (MANOVA), Pearson Korelasyon Testi ve Çoklu Doğrusal Regresyon analizleri uygulanmıştır.

\section{BULGULAR}

\section{Katılımcıların Demografik Özelliklerine İlişkin Bulgular}

Spor gönüllüsü katılımcıların demografik özelliklerine ilişkin bulgular incelendiğinde; $\% 37,1$ 'inin kadın ve \%62,9'unun ise erkek katılımcılardan oluştuğu; bununla birlikte \%1,1'inin ilköğretim, \%23,6'sının lise, \%70 gibi büyük bir çoğunluğunun lisans ve \%5,3'ünün ise lisansüstü eğitim aldığı tespit edilmiştir. Meslek sektörü açısından incelendiğinde ise, gönüllü katılımcıların \%58,8 gibi büyük bir çoğunluğunun öğrenci olduğu, \%7,5'lik bir kesimin kamu sektöründe çalıştığ $1, \% 20,2$ 'lik bir bölümün özel sektörde çalıştığ1 ve \%13,5'lik bir kesimin ise herhangi bir işte çalışmadığını belirtmiştir. 
Tablo 2. Katılımcıların demografik özelliklerine ilişkin bulgular

\begin{tabular}{|c|c|c|c|c|}
\hline Değișkenler & Alt Grup & $\mathbf{N}$ & $\%$ & Toplam \\
\hline Cinsiyet & $\begin{array}{l}\text { Kadın } \\
\text { Erkek }\end{array}$ & $\begin{array}{c}99 \\
168\end{array}$ & $\begin{array}{l}37,1 \\
62,9 \\
\end{array}$ & 267 \\
\hline \multirow{4}{*}{ Ĕ̆itim } & İlköğretim & 3 & 1,1 & \multirow{4}{*}{267} \\
\hline & Lise & 63 & 23,6 & \\
\hline & Lisans & 187 & 70,0 & \\
\hline & Lisansüstü & 14 & 5,3 & \\
\hline \multirow{4}{*}{ Meslek } & Öğrenci & 157 & 58,8 & \multirow{4}{*}{267} \\
\hline & Kamu Sektörü & 20 & 7,5 & \\
\hline & Özel Sektör & 54 & 20,2 & \\
\hline & İși Olmayan & 36 & 13,5 & \\
\hline \multirow{3}{*}{ Sporla İlgilenim } & Bireysel & 109 & 40,8 & \multirow{3}{*}{267} \\
\hline & Takım & 84 & 31,5 & \\
\hline & Spor Yapmayan & 74 & 27,7 & \\
\hline \multirow{4}{*}{$\begin{array}{c}\text { Katıldığı } \\
\text { Organizasyon }\end{array}$} & Balkan Salon Atletizm & 160 & 59,9 & \multirow{4}{*}{267} \\
\hline & Vodafone İstanbul Maratonu & 69 & 25,9 & \\
\hline & UEFA Süper Kupa Finali & 27 & 10,1 & \\
\hline & Boğaziçi Kitalararası Yüzme & 11 & 4,1 & \\
\hline
\end{tabular}

Gönüllü katılımcıların sporla ilgilenim durumları incelendiğinde ise, \%40,8'inin bireysel, \%31,5'inin takım sporlarıyla ilgilendiği ve \%27,7'sinin ise herhangi bir spor aktivitesiyle ilgilenmediği tespit edilmiştir. Gönüllülerin spor organizasyonlarına katılım dağılımları ise; \%59,9 Balkan Salon Atletizm Şampiyonası, \%25,9’u Vodafone İstanbul Maratonu, \%10,1'i UEFA Süper Kupa Finali ve \%4,1’i ise Boğaziçi Kıtalararası Yüzme Yarışı şeklindedir.

\section{Katılımcıların Gönüllülük Motivasyonu ve Serbest Zaman Doyum Düzeylerine İlişkin Bulgular}

Çalışmada kullanılan ölçeklerin alt boyutlarına ve toplam puanına ilişkin aritmetik ortalama ve standart sapma değerleri tabloda sunulmuştur. Sonuçlar incelendiğinde Uluslararası Spor Organizasyonları İçin Gönüllü Motivasyonu Ölçeği puanları açısından, gönüllü katılımcılar için en yüksek puan ortalamasına sahip motivasyon faktörünün "değerlerin ifadesi" boyutu olduğu görülmektedir. Bu faktörle birlikte, "spor sevgisi”, "vatanseverlik" ve "kişilerarası ilişkiler" boyutlarının da gönüllü katılımcılar için yüksek puan ortalamasına sahip motivasyon faktörleri olduğu söylenebilir. Aritmetik ortalama puanlarına göre bu faktörleri takiben, "kariyer yönlendirme” boyutu gelirken, "dışsal ödüller" boyutu ise gönüllü katılımcıların motivasyon faktörleri arasında en az puan ortalamasına sahip motivasyon faktörü olduğu tespit edilmiştir.

Tablo 3. Ölçeklere ilişkin aritmetik ortalama ve standart sapma puanları

\begin{tabular}{|c|c|c|c|c|}
\hline & & $\overline{\mathbf{X}}$ & $\mathbf{S}$ & $\mathbf{N}$ \\
\hline \multirow{7}{*}{$\begin{array}{l}\sum_{0}^{0} \\
0 \\
0 \\
0 \\
0\end{array}$} & Vatanseverlik & 6,37 & 9511 & 267 \\
\hline & Değerlerin İfadesi & 6,60 & ,7540 & 267 \\
\hline & Spor Sevgisi & 6,50 & ,7814 & 267 \\
\hline & Kariyer Yönlendirme & 5,94 & 1,2531 & 267 \\
\hline & Kişilerarası İlişkiler & 6,25 & 1,0099 & 267 \\
\hline & Dışsal Ödüller & 3,37 & 1,4985 & 267 \\
\hline & Genel Motivasyon & 5,95 & ,7589 & 267 \\
\hline \multirow{7}{*}{ : } & Psikolojik & 4,27 & ,7678 & 267 \\
\hline & Eğitimsel & 4,35 & ,7458 & 267 \\
\hline & Sosyal & 4,34 & 6929 & 267 \\
\hline & Fiziksel & 4,41 & 6880 & 267 \\
\hline & Rahatlama & 3,87 & 8496 & 267 \\
\hline & Estetik & 4,17 & 7781 & 267 \\
\hline & Genel Doyum & 4,24 & ,6284 & 267 \\
\hline
\end{tabular}


Serbest Zaman Doyum Ölçeği alt boyutları ve toplam puanına ilişkin sonuçlar incelendiğinde ise; gönüllü katılımcılar adına serbest zaman doyumu açısından en yüksek puan ortalamasına sahip faktörlerin sırasıyla "fiziksel", "eğitimsel" ve "sosyal" boyutlar olduğu tespit edilmiştir. Puanlar ve serbest zaman doyumu açısından bu faktörleri "psikolojik" ve "estetik" boyutları takip ederken, "rahatlama" boyutunun serbest zaman doyumuna gönüllü katılımcılar açısından en az katkı sağlayan faktör olduğu belirlenmiştir.

\section{Cinsiyet Değişkenine Göre Bağımsız Örneklemler İçin T-Testi Sonuçları}

Cinsiyet değişkenine göre USOGMÖ Bağımsız Örneklemler İçin T-Testi analiz sonuçları incelendiğinde, "değerlerin ifadesi" alt boyutunda bir anlamlılık tespit edilmiş olup, bu anlamlılığın kadınlar lehine olduğu söylenebilir $(\mathrm{p}<.05)$. Yine cinsiyet değişkeni açısından vatanseverlik, spor sevgisi, kariyer yönlendirme, kişilerarası ilişkiler ve dişsal ödüller alt boyutlarında herhangi bir anlamlı farklılık tespit edilmemiştir ( $\mathrm{p}>.05)$. Cinsiyet değişkeni açısından USOGMÖ toplam puanında herhangi bir anlamlı farklılık tespit edilmemiştir ( $>$ >.05).

Tablo 4. Cinsiyet değișkenine göre USOGMÖ bağımsız örneklemler için T-testi analiz sonuçları

\begin{tabular}{|c|c|c|c|c|c|c|c|}
\hline & Cinsiyet & $\mathbf{N}$ & $\overline{\mathbf{X}}$ & $\mathbf{S}$ & sd & $\mathbf{t}$ & p \\
\hline \multirow{2}{*}{ Vatanseverlik } & Kadın & 99 & 6,458 &, 852 & \multirow{2}{*}{265} & \multirow{2}{*}{1,039} & \multirow{2}{*}{,300 } \\
\hline & Erkek & 168 & 6,333 & 1,004 & & & \\
\hline \multirow{2}{*}{ Değerlerin İfadesi } & Kadın & 99 & 6,750 & ,489 & \multirow{2}{*}{264,674} & \multirow{2}{*}{2,694} & \multirow{2}{*}{, $008 *$} \\
\hline & Erkek & 168 & 6,526 &, 863 & & & \\
\hline \multirow{2}{*}{ Spor Sevgisi } & Kadın & 99 & 6,588 & ,710 & \multirow{2}{*}{265} & \multirow{2}{*}{1,285} & \multirow{2}{*}{,200 } \\
\hline & Erkek & 168 & 6,461 & ,818 & & & \\
\hline \multirow{2}{*}{ Kariyer Yönlendirme } & Kadın & 99 & 5,800 & 1,493 & \multirow{2}{*}{265} & \multirow{2}{*}{$-1,427$} & \multirow{2}{*}{, 155} \\
\hline & Erkek & 168 & 6,026 & 1,083 & & & \\
\hline \multirow{2}{*}{ Kişilerarası İlişkiler } & Kadın & 99 & 6,252 & 1,063 & \multirow{2}{*}{265} & \multirow{2}{*}{,- 004} & \multirow{2}{*}{,997 } \\
\hline & Erkek & 168 & 6,253 & ,980 & & & \\
\hline \multirow{2}{*}{ Dışsal Ödüller } & Kadın & 99 & 3,279 & 1,390 & \multirow{2}{*}{265} & \multirow{2}{*}{,- 837} & \multirow{2}{*}{,403 } \\
\hline & Erkek & 168 & 3,438 & 1,559 & & & \\
\hline USOGMÖ Toplam & Kadın & 99 & 5,947 &, 692 & 265 &,- 128 & ,899 \\
\hline
\end{tabular}

Cinsiyet değişkenine göre SZDÖ Bağımsız Örneklemler İçin T-Testi analiz sonuçları incelendiğinde, cinsiyet değişkeni açısından SZDÖ psikolojik, eğitimsel, sosyal, fiziksel, rahatlama ve estetik alt boyutları ile toplam puanında herhangi bir anlamlı farklılık tespit edilmemiştir ( $\mathrm{p}>.05)$.

Tablo 5. Cinsiyet değişkenine göre SZDÖ bağımsız örneklemler için T-testi analiz sonuçları

\begin{tabular}{|c|c|c|c|c|c|c|c|}
\hline & Cinsiyet & $\mathbf{N}$ & $\overline{\mathbf{X}}$ & $\mathbf{S}$ & sd & $\mathbf{t}$ & p \\
\hline \multirow[t]{2}{*}{ Psikolojik } & Kadın & 99 & 4,267 &, 826 & \multirow{2}{*}{265} & \multirow{2}{*}{,- 185} & \multirow{2}{*}{, 853} \\
\hline & Erkek & 168 & 4,285 & ,733 & & & \\
\hline \multirow[t]{2}{*}{ Eğitimsel } & Kadın & 99 & 4,401 & ,806 & \multirow{2}{*}{265} & \multirow{2}{*}{,705 } & \multirow{2}{*}{,481 } \\
\hline & Erkek & 168 & 4,334 & ,709 & & & \\
\hline \multirow[t]{2}{*}{ Sosyal } & Kadın & 99 & 4,343 & ,753 & \multirow{2}{*}{265} & \multirow{2}{*}{,047 } & \multirow{2}{*}{,962 } \\
\hline & Erkek & 168 & 4,339 & ,656 & & & \\
\hline \multirow[t]{2}{*}{ Fiziksel } & Kadın & 99 & 4,497 & 663 & \multirow{2}{*}{265} & \multirow{2}{*}{1,546} & \multirow{2}{*}{,123 } \\
\hline & Erkek & 168 & 4,363 & ,699 & & & \\
\hline \multirow[t]{2}{*}{ Rahatlama } & Kadın & 99 & 3,742 & ,954 & \multirow{2}{*}{265} & \multirow{2}{*}{$-1,918$} & \multirow{2}{*}{,056 } \\
\hline & Erkek & 168 & 3,947 & ,774 & & & \\
\hline \multirow[t]{2}{*}{ Estetik } & Kadın & 99 & 4,227 & ,799 & \multirow{2}{*}{265} & \multirow{2}{*}{,810 } & \multirow{2}{*}{,418 } \\
\hline & Erkek & 168 & 4,147 & ,766 & & & \\
\hline \multirow{2}{*}{ SZDÖ Toplam } & Kadın & 99 & 4,246 & ,672 & \multirow{2}{*}{265} & \multirow{2}{*}{,129 } & \multirow{2}{*}{,898 } \\
\hline & Erkek & 168 & 4,236 &, 602 & & & \\
\hline
\end{tabular}




\section{Çok Değişkenli Varyans Analizi (MANOVA) Testi Sonuçları}

USOGMÖ altı faktöre ait çok değişkenli varyans analizi MANOVA testi sonuçları incelendiğinde; Pillai's Trace, Wilks' Lambda, Hotelling's Trace ve Roy's Largest Root testleri sonuçlarına göre, sporla ilgilenim düzeylerinde anlamlı farklılık tespit edilmiştir $(\mathrm{p}<.05)$. Bununla birlikte yapılan analiz sonuçlarına göre, cinsiyet ve cinsiyet-sporla ilgilenim değişkenleri açısından anlamlı bir farklılık tespit edilmemiştir ( $\mathrm{p}>05$ ).

Tablo 6. USOGMÖ altı faktöre ait çok değişkenli varyans analizi (MANOVA) testi sonuçları

\begin{tabular}{|c|c|c|c|c|c|c|}
\hline Etki & & Değer & $\mathbf{F}$ & Hipotez sd & Hata sd & $\mathbf{p}$ \\
\hline \multirow{4}{*}{ Sabit Terim } & Pillai's Trace & ,986 & $9066,691^{b}$ & 2,000 & 260,000 &, 000 \\
\hline & Wilks' Lambda & ,014 & $9066,691^{\mathrm{b}}$ & 2,000 & 260,000 & , 000 \\
\hline & Hotelling's Trace & 69,744 & $9066,691^{\mathrm{b}}$ & 2,000 & 260,000 & ,000 \\
\hline & Roy's Largest Root & 69,744 & $9066,691^{b}$ & 2,000 & 260,000 & 000 \\
\hline \multirow{4}{*}{ Cinsiyet } & Pillai's Trace & ,004 &, $524^{\mathrm{b}}$ & 2,000 & 260,000 & ,593 \\
\hline & Wilks' Lambda & ,996 &, $524^{\mathrm{b}}$ & 2,000 & 260,000 & ,593 \\
\hline & Hotelling's Trace & ,004 &, $524^{\mathrm{b}}$ & 2,000 & 260,000 & ,593 \\
\hline & Roy's Largest Root & ,004 &, $524^{\mathrm{b}}$ & 2,000 & 260,000 & ,593 \\
\hline \multirow{4}{*}{ Sporla İlgilenim } & Pillai's Trace & ,065 & 4,383 & 4,000 & 522,000 &, $002 *$ \\
\hline & Wilks' Lambda & ,935 & $4,424^{b}$ & 4,000 & 520,000 &, $002 *$ \\
\hline & Hotelling's Trace & ,069 & 4,465 & 4,000 & 518,000 &, $001 *$ \\
\hline & Roy's Largest Root & ,065 & $8,461^{\mathrm{c}}$ & 2,000 & 261,000 &, $000 *$ \\
\hline \multirow{4}{*}{$\begin{array}{l}\text { Cinsiyet ve Sporla } \\
\text { İlgilenim }\end{array}$} & Pillai's Trace & ,019 & 1,243 & 4,000 & 522,000 & ,292 \\
\hline & Wilks' Lambda & ,981 & $1,244^{\mathrm{b}}$ & 4,000 & 520,000 & ,291 \\
\hline & Hotelling's Trace & 019 & 1,245 & 4,000 & 518,000 & ,291 \\
\hline & Roy's Largest Root & ,019 & $2,496^{\mathrm{c}}$ & 2,000 & 261,000 & ,084 \\
\hline
\end{tabular}

*p<.05

SZDÖ altı faktöre ait çok değişkenli varyans analizi MANOVA testi sonuçları incelendiğinde, Pillai's Trace, Wilks' Lambda, Hotelling's Trace ve Roy's Largest Root testleri sonuçlarına göre, sporla ilgilenim düzeylerinde anlamlı farklılık göstermiştir $(\mathrm{p}<.05)$. Cinsiyet ve cinsiyetsporla ilgilenim değişkenleri açısından anlamlı bir farklılık bulunmamıştır ( $\mathrm{p}>.05)$.

Tablo 7. SZDÖ altı faktöre ait çok değişkenli varyans analizi (MANOVA) testi sonuçları

\begin{tabular}{|c|c|c|c|c|c|c|}
\hline Etki & & Değer & $\mathbf{F}$ & Hipotez sd & Hata sd & $\mathbf{p}$ \\
\hline \multirow{4}{*}{ Sabit Terim } & Pillai's Trace & ,989 & $3747,935^{\mathrm{b}}$ & 6,000 & 256,000 & ,000 \\
\hline & Wilks' Lambda & ,011 & $3747,935^{\mathrm{b}}$ & 6,000 & 256,000 & ,000 \\
\hline & Hotelling's Trace & 87,842 & $3747,935^{\mathrm{b}}$ & 6,000 & 256,000 &, 000 \\
\hline & Roy's Largest Root & 87,842 & $3747,935^{\mathrm{b}}$ & 6,000 & 256,000 & ,000 \\
\hline \multirow{4}{*}{ Cinsiyet } & Pillai's Trace &, 043 & $1,924^{b}$ & 6,000 & 256,000 & ,077 \\
\hline & Wilks' Lambda & ,957 & $1,924^{\mathrm{b}}$ & 6,000 & 256,000 & ,077 \\
\hline & Hotelling's Trace & ,045 & $1,924^{\mathrm{b}}$ & 6,000 & 256,000 & 077 \\
\hline & Roy's Largest Root & 045 & $1,924^{\mathrm{b}}$ & 6,000 & 256,000 & ,077 \\
\hline \multirow{4}{*}{ Sporla İlgilenim } & Pillai's Trace & ,086 & 1,922 & 12,000 & 514,000 & ,030* \\
\hline & Wilks' Lambda & ,915 & $1,935^{\mathrm{b}}$ & 12,000 & 512,000 & ,028* \\
\hline & Hotelling's Trace & ,092 & 1,949 & 12,000 & 510,000 &, $027^{*}$ \\
\hline & Roy's Largest Root & ,078 & $3,331^{\mathrm{c}}$ & 6,000 & 257,000 &, $004 *$ \\
\hline \multirow{4}{*}{$\begin{array}{l}\text { Cinsiyet ve Sporla } \\
\text { İlgilenim }\end{array}$} & Pillai's Trace & ,074 & 1,636 & 12,000 & 514,000 &, 078 \\
\hline & Wilks' Lambda & ,928 & $1,636^{\mathrm{b}}$ & 12,000 & 512,000 & ,078 \\
\hline & Hotelling's Trace & ,077 & 1,636 & 12,000 & 510,000 & ,078 \\
\hline & Roy's Largest Root & ,056 & $2,380^{\mathrm{c}}$ & 6,000 & 257,000 & 030 \\
\hline
\end{tabular}


Yapılan analiz testi sonuçları incelendiğinde, USOGMÖ "vatanseverlik" alt boyutu ile SZDÖ psikolojik $(\mathrm{r}=.154)$, eğitimsel $(\mathrm{r}=.186)$, sosyal $(\mathrm{r}=.147)$, fiziksel $(\mathrm{r}=.189)$, rahatlama $(\mathrm{r}=.168)$ ve estetik $(r=.238)$ alt boyutları arasında pozitif yönde düşük düzeyde ilişki tespit edilmiştir $(\mathrm{p}<.05)$. USOGMÖ “değerlerin ifadesi” alt boyutu ile SZDÖ psikolojik ( $\mathrm{r}=.160)$, eğitimsel $(\mathrm{r}=.233)$, sosyal $(\mathrm{r}=.181)$, fiziksel $(\mathrm{r}=.239)$ ve estetik $(\mathrm{r}=.209)$ alt boyutlarında pozitif yönde, düşük düzeyde ilişki tespit edilirken $(\mathrm{p}<.05)$; SZDÖ "rahatlama" alt boyutu ile anlamlı bir farklılık saptanmamıştır ( $\mathrm{p}>.05)$.

Tablo 8. USOGMÖ ve SZDÖ alt boyutlarına ilişkin Pearson korelasyon testi sonuçları

\begin{tabular}{lccccccc}
\hline & & Psikolojik & Eğitimsel & Sosyal & Fiziksel & Rahatlama & Estetik \\
\hline Vatanseverlik & $\mathrm{r}$ &, $154^{*}$ &, $186^{* *}$ &, $147^{*}$ &, $189^{* *}$ &, $168^{* *}$ &, $238^{* *}$ \\
Değerlerin İfadesi & $\mathrm{r}$ &, $160^{* *}$ &, $233^{* *}$ &, $181^{* *}$ &, $239^{* *}$ &, 045 &, $209^{* *}$ \\
Spor Sevgisi & $\mathrm{r}$ &, $154^{*}$ &, $188^{* *}$ &, $211^{* *}$ &, $242^{* *}$ &, $239^{* *}$ &, $185^{* *}$ \\
Kariyer Yönlendirme & $\mathrm{r}$ &, $353^{* *}$ &, $351^{* *}$ &, $455^{* *}$ &, $307^{* *}$ &, $384^{* *}$ &, $317^{* *}$ \\
Kişilerarası İlişkiler & $\mathrm{r}$ &, $395^{* *}$ &, $439^{* *}$ &, $474^{* *}$ &, $366^{* *}$ &, $346^{* *}$ &, $323^{* *}$ \\
Dışsal Ödüller & $\mathrm{r}$ &, $226^{* *}$ &, $192^{* *}$ &, $254^{* *}$ &, $196^{* *}$ &, $364^{* *}$ &, $307^{* *}$ \\
\hline *p<.05 ve ***p<.01 & & & & & & &
\end{tabular}

Yine USOGMÖ "spor sevgisi” alt boyutu ile SZDÖ psikolojik ( $\mathrm{r}=.154)$ eğitimsel $(\mathrm{r}=.188)$, sosyal $(\mathrm{r}=.211)$, fiziksel $(\mathrm{r}=.242)$, rahatlama $(\mathrm{r}=.239)$ ve estetik $(\mathrm{r}=.185)$ alt boyutları arasında pozitif yönde, düşük düzeyde ilişki tespit edilmiştir ( $\mathrm{p}<.05)$. USOGMÖ "kariyer yönlendirme" alt boyutu ile SZDÖ psikolojik ( $\mathrm{r}=.353)$, eğitimsel $(\mathrm{r}=.351)$, sosyal $(\mathrm{r}=.455)$, fiziksel $(\mathrm{r}=.307)$, rahatlama $(\mathrm{r}=.384)$ ve estetik $(\mathrm{r}=.317)$ alt boyutları arasında pozitif yönde, orta düzeyde ilişki tespit edilmiştir $(\mathrm{p}<.05)$. USOGMÖ "kişilerarası ilişkiler" alt boyutu ile SZDÖ psikolojik $(r=395)$, eğitimsel $(r=.439)$, sosyal $(r=.474)$, fiziksel $(r=.366)$, rahatlama $(r=.346)$ ve estetik $(\mathrm{r}=.323)$ alt boyutları arasında pozitif yönde, orta düzeyde ilişki tespit edilmiştir $(\mathrm{p}<.05)$. USOGMÖ “dişsal ödüller” alt boyutu ile SZDÖ rahatlama $(\mathrm{r}=.364)$ ve estetik $(\mathrm{r}=.307)$ alt boyutlarında pozitif yönde, orta düzeyde $(\mathrm{p}<.05)$; ve psikolojik $(\mathrm{r}=.226)$, eğitimsel $(\mathrm{r}=.192)$, sosyal $(\mathrm{r}=.254)$ ve fiziksel $(\mathrm{r}=.196)$ alt boyutları arasında pozitif yönde, düşük düzeyde ilişki saptanmıştır $(\mathrm{p}<.05)$.

Tablo 9. Gönüllü motivasyonu ve serbest zaman doyumu korelasyon testi sonuçları

\begin{tabular}{lcc}
\hline & & Serbest Zaman Doyumu \\
\hline \multirow{2}{*}{ Gönüllü Motivasyonu } & $\mathrm{r}$ &, $431^{* *}$ \\
& $\mathrm{p}$ &, 000 \\
& $\mathrm{~N}$ & 267 \\
\hline$* * \mathrm{p}<.05$ & &
\end{tabular}

Tabloda analiz sonuçları incelendiğinde, gönüllülük faaliyetlerine katılım gösteren bireylerin genel gönüllülük motivasyonu ile serbest zaman doyum düzeyleri arasında pozitif yönde, orta düzeyde ilişki tespit edilmiştir $(\mathrm{r}=.431, \mathrm{p}<.05)$. 
Er, B. ve Güzel Gürbüz, P. (2021). Uluslararası spor organizasyonlarında gönüllü motivasyonu ile serbest zaman doyum düzeyi arasındaki ilişkinin incelenmesi. Spor Bilimleri Araştırmaları Dergisi, 6(1), 152-172.

Tablo 10. SZDÖ toplam puanı ve USOGMÖ alt boyutlarına ilişkin çoklu doğrusal regresyon analizi sonuçları

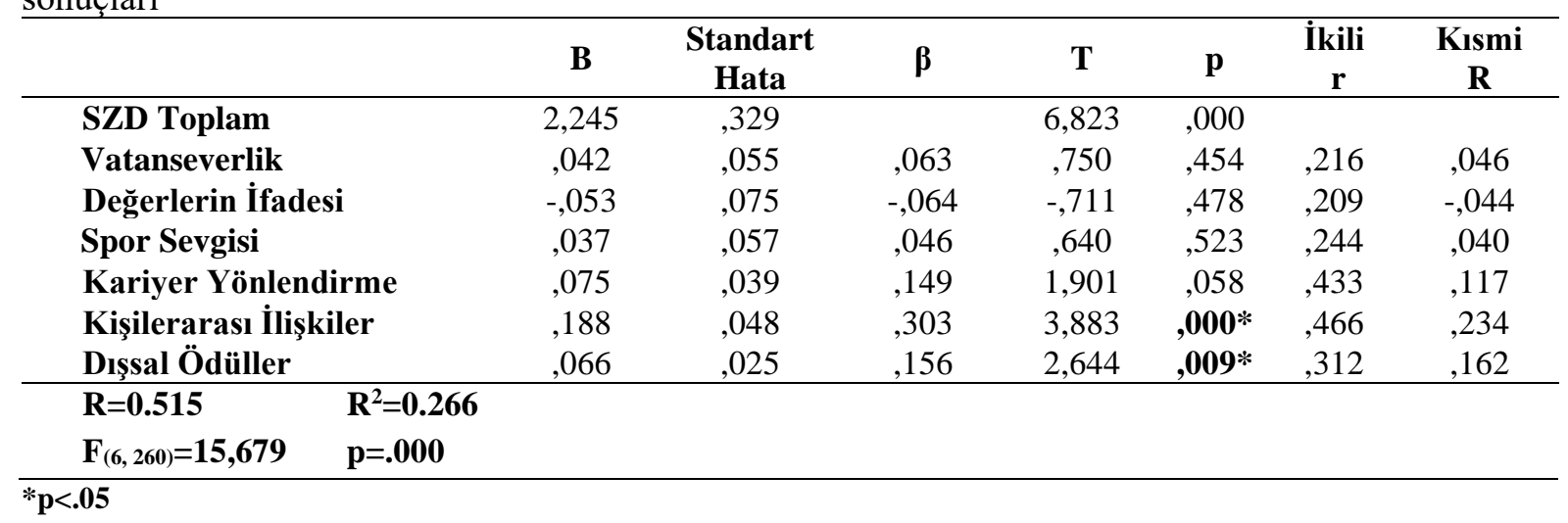

"Kişilerarası ilişkiler" ve "dışsal ödüller" değişkenleri birlikte, serbest zaman doyum puanları ile yüksek düzeyde ve anlamlı bir ilişki vermektedir $\left(\mathrm{R}=0.515, \mathrm{R}^{2}=0.266, \mathrm{p}<.01\right)$. Adı geçen iki değişken birlikte, serbest zaman doyum toplam varyansın \%27'sini açıklamaktadır.

Standardize edilmiş regresyon katsayısına $(\beta)$ göre, yordayıcı değişkenlerin serbest zaman doyumu üzerindeki göreli önem sırası kişilerarası ilişkiler, dışsal ödüller, kariyer yönlendirme, değerlerin ifadesi, vatanseverlik ve spor sevgisi şeklindedir. Regresyon katsayılarının anlamlılığına ilişkin T-Testi sonuçları incelendiğinde ise, kişilerarası ilişkiler ve dışsal ödüller değişkenlerinin serbest zaman doyumu üzerinde anlamlı bir yordayıcı olduğu görülmektedir. Kariyer yönlendirme, spor sevgisi, değerlerin ifadesi ve vatanseverlik değişkenleri ise önemli bir etkiye sahip değildir.

\section{TARTIŞMA-SONUÇ}

Uluslararası spor organizasyonlarında görev alan gönüllülerin motivasyon faktörleri ile serbest zaman doyum düzeyleri arasındaki ilişkinin karşılaştırılması ve farklı demografik değişkenlere göre incelenmesi amaciyla gerçekleştirilen bu çalışmada; gönüllü motivasyonu faktörlerinde aritmetik ortalama puanları baz alınarak, gönüllülerin en yüksek puan ortalamasını içeren motivasyon kaynağının "değerlerin ifadesi" boyutu olduğu tespit edilmiştir. Gönüllüler açısından "değerlerin ifadesi" faktörünü takiben, "spor sevgisi", "vatanseverlik" ve "kişilerarası ilişkiler" boyutlarının da gönüllü katılımcılar için yüksek puan ortalamasına sahip motivasyon faktörleri olduğu söylenebilir. Bu boyutları sırasıyla, "kariyer yönlendirme" faktörü takip ederken, "dışsal ödüller" boyutunun ise gönüllü katılımcıların en az motive oldukları faktör olarak ifade edilebilir.

Serbest zaman doyum düzeyleri açısından gönüllü katılımcıların aritmetik ortalama puanı sonuçları incelendiğinde ise; genel serbest zaman doyumu açısından doyum düzeylerinin oldukça yüksek olduğu tespit edilmiştir. Bununla birlikte en yüksek puan ortalamasına sahip serbest zaman doyumu boyutlarının sırasıyla fiziksel, eğitimsel, sosyal, psikolojik ve estetik boyutlarında olduğu tespit edilirken; rahatlama düzeyinde serbest zaman doyumunun diğer alt boyutlara göre daha düşük olduğu saptanmıştır.

Cinsiyet değişkenine göre gönüllü motivasyon faktörleri incelendiğinde ise, kadın gönüllü katılımcıların erkeklere göre değerlerin ifadesi alt boyutunda daha fazla motive oldukları tespit edilmiştir. Fletcher ve Major (2004) tıp öğrencileri ile yaptıkları çalışma sonucunda, cinsiyet 
değişkeni açısından kadınların, özgecil (altruistik) başkalarına yardım etme duygularını içeren "değerler" boyutunda gönüllü olma motivasyonunun erkeklerden daha yüksek olduğu belirtilmiştir. Yine Berber ve Terekli (2019) yapmış oldukları çalışmada, cinsiyet değişkeni açısından gönüllülük motivasyonlarında kadın katılımcılar lehine anlamlı bir farklılık olduğunu tespit etmişlerdir.

Widjaja (2010) ise cinsiyet değişkeni açısından kadınların gönüllülüğe daha eğilimli olduklarını belirtmiştir. Chapman ve Morley (1999) yaptıkları çalışmada cinsiyet değişkeni açısından kadın gönüllülerin güncel çalışmayla benzer şekilde değerler alt boyutunda olmakla birlikte, bazı gönüllü motivasyonu faktörlerinde erkek gönüllü katılımcılara göre önemli derecede motive olduklarını ifade etmişlerdir. Aynı çalışma kadınların erkeklere göre daha fazla motive olması sonucunu, sosyal rol teorisi ile açıklanabileceğini belirtmiştir. Sosyal rol teorisi, kadınların erkeklere göre daha fazla yetiştirme eğiliminin bir fonksiyonu olarak davranışa yardımcı olma olasılıklarının daha yüksek olduğunu ve bu cinsiyet farkının erken sosyalleşme süreçlerinin bir işlevi olabileceğini düşündürmektedir. Daha önce yapılan araştırmalar, değerler fonksiyonu tarafından motive olan gönüllülerin yetiştirme ve sosyal sorumluluk ölçümleri üzerinde yüksek puan alması ve bu nedenle, değerler güdüsünün kadınlar için daha önemli bir güdü olmasının beklenebileceğini belirtmiştir. Bu sonuçlar güncel çalışma ile benzerlik göstermektedir.

Cinsiyet değişkenine göre gönüllülük faaliyetlerine katılım gösteren bireylerin, serbest zaman doyum düzeyleri açısından herhangi bir ilişki tespit edilmemiştir. Riddick (1986), Broughton ve Beggs (2007), Ardahan ve Lerlisu Lapa (2010), Çelik (2011) ile Cengiz ve Yaşartürk (2020) tarafından yapılan çalışmalarda da benzer şekilde cinsiyet ile serbest zaman doyum düzeyleri arasında anlamlı bir fark bulunmamıştır. $\mathrm{Bu}$ durum serbest zamanlarında gönüllülük faaliyetlerine katılım gösteren bireylerin, cinsiyet değişkeni açısından serbest zaman doyum düzeyleriyle herhangi bir fark yaratmaması olarak yorumlanabilir.

Sporla ilgilenim değişkenin, gönüllü katılımcıların motivasyon faktörleri üzerinde etkisi olduğu görülmektedir. Diğer yandan test sonuçları, cinsiyet ile sporla ilgilenim ve cinsiyet değişkenlerinin bir arada gönüllü katılımcıların motivasyon faktörlerinin üzerinde etkisi olmadığını göstermiştir. Benzer şekilde Pauline ve Pauline (2009) 2005 Indianapolis Tenis Şampiyonası'nda 289 spor gönüllüsü ile yaptı̆̆ çalışmada cinsiyet değişkeninin motivasyon faktörleri üzerinde bir etkisi olmadığını tespit etmiştir.

Downward ve Ralston'un (2006) bir spor etkinliğinde gönüllü olmanın, ilgiyi, katılımı, gelecekteki spora gönüllülüğü nasıl etkilediğini araştırma amacıyla yaptığı çalışmanın sonuçları incelendiğinde; katılımcıların gönüllülük deneyiminin bir sonucu olarak sporla ilgilenimlerinde bir miktar artış olduğuna dair kanıtlar olsa da bunun daha fazla katılım veya gönüllülüğe dönüşeceğine dair güçlü bir kanıt olmadığını göstermektedir. Dawson ve Downward (2013) ise spora katılım ile spor gönüllülüğü arasındaki ilişkiyi inceledikleri çalışmada, spor katılımı ve sporda gönüllülük faaliyetlerine katılma kararının tamamlayıcı unsurlar olduğunu belirtmişlerdir.

Gönüllü katılımcıların cinsiyet, sporla ilgilenim ve cinsiyet ile sporla ilgilenim değişkenlerinin bir arada serbest zaman doyumuna etkisinin test sonuçlarında sporla ilgilenim değişkeninin serbest zaman doyum düzeyleri üzerinde etkisi olduğu görülmektedir. Benzer şekilde Doğan 
ve diğerleri (2018) tarafından akademisyenler üzerine yapılan bir çalı̧̧ada, serbest zaman doyum düzeyinin spora katılım durumuna göre anlamlı fark gösterdiği tespit edilmiştir. Bu durum sporla ilgilenimi olan bireylerin serbest zaman doyum düzeylerinin daha yüksek olması şeklinde yorumlanabilir. Bununla birlikte cinsiyet ile cinsiyet ve sporla ilgilenim değişkenlerinin bir arada serbest zaman doyum düzeyleri üzerinde etkisi olmadığı tespit edilmiştir.

Moon ve Heo (2011) herkes için spor katılımının serbest zaman doyumu, psikolojik refah ve öznel refah üzerindeki etkisini inceledikleri çalışmada, bireylerin spora katılımının, serbest zaman doyum düzeyleri üzerinde bir etkiye sahip olduğunu belirtmişlerdir. Kim ve Han (2005) ise dans sporlarına katılımın, serbest zaman akış deneyiminin ve serbest zaman doyumunun zevk kaynakları arasındaki nedensel ilişkiyi bulma amacıyla yaptıkları çalışmada, dans sporlarına katılımın zevk kaynaklarının, serbest zaman doyumu üzerinde önemli ölçüde olumlu etkileri olduğunu tespit etmişlerdir.

Korelasyon testi sonuçları incelendiğinde; bireylerin sporda gönüllülük faaliyetlerine bir serbest zaman faaliyeti olarak katılım gösterdikleri ve etkinlikte elde ettikleri doyum düzeyleri ile motivasyon faktörleri arasındaki ilişkinin özellikle kariyer yönlendirme ve kişilerarası ilişkiler faktörleri ile serbest zaman doyum faktörleri arasındaki düzeyin önemi göze çarpmaktadır. $\mathrm{Bu}$ sonuçlara göre uluslararası spor organizasyonlarında gönüllülük faaliyetlerine katılım gösteren bireylerin, motivasyon faktörleri ile serbest zaman doyum düzeyleri arasında önemli bir ilişki olduğu söylenebilir.

Uygulanan çoklu doğrusal regresyon analizi sonuçları incelendiğinde ise, gönüllü katılımcıların gönüllülük motivasyonu faktörlerinden kişilerarası ilişkiler ve dışsal ödüller boyutlarının serbest zaman doyum düzeylerine etki ettiği görülmektedir. Bu durum kişilerarası ilişkiler ve dışsal ödüller faktörleri açısından daha fazla motive olan gönüllülerin, serbest zaman doyum düzeylerinin de artacağı şeklinde yorumlanabilir.

Parker'ın (1997) ifade ettiği gibi birey değerli olduğuna inanılan bir nedene kendini özgürce verebilir ve kolektif bir serbest zaman deneyimi olarak serbest zamanlarda yardımlaşma ya da bir şeyler üretme amacıyla da toplukla birlikte gönüllü olabilir. Ayrıca Taylor ve diğerleri (2008) içsel ve finansal olmayan ödüllerin, yani başkalarına yardım etme, iletişim kurma, sosyal faydalar ve becerilerine katkıda bulunarak fark yaratma kişisel ödüllerinin spor organizasyonlarında bireyleri gönüllü olmaya motive ettiğini belirtmiştir. Bunun yanında finansal olmayan dışsal ödüller de gönüllülerin katkıları ve performansının takdiri gibi sembolik ifadelerle motive olması açısından önemli olduğunu belirtmişlerdir.

Ringuet (2012) gönüllülerin birçok nedenden gönüllü olmaya motive olduğunu ifade ederken, çoğu birey için bu durumun bir serbest zaman seçimi olduğunu belirtmiştir. Getz de (2008) gönüllülerin temel motivasyon faktörlerini özgecilik (altruizm), sosyal ve kariyer faydaları ile meydan okuma gibi genel motivasyonları ifade edebileceğini ifade etmiştir. Gönüllülerin topluluğun, deneyimlerle oluşabilecek aidiyet ve paylaşımın tadını çıkarabileceğini ve aynı zamanda gönüllülüğün "ciddi serbest zamanların” bir gösterimi olarak etkinlikte yer alabileceklerini belirtmiştir. Gönüllü birey bu etkinliklerde yaşadığı deneyim sayesinde, başkalarını da gönüllülüğe motive edebilmesine yol açtığı vurgulanmıştır. 
Downward ve Ralston'un (2006) çalışmalarında, sporda gönüllülük faaliyetlerine katılımı Ciddi Serbest Zaman yaklaşımı ile ilişkilendirmiş ve gönüllülüğün potansiyel bir kariyer sağlayabileceğini belirtmişlerdir. Belirli bir etkinliğe gündelik katılımın, bireyin düzenli gönüllülüğe veya belirli bir spora katılımına yol açabileceği belirtilmiştir.

Çalışma sonuçları ve literatür ile birlikte, motivasyon ve serbest zaman yaklaşımları da göz önüne alındığında; uluslararası spor organizasyonlarında görev alan gönüllülerin serbest zaman doyumu ve motivasyon faktörleri arasında güçlü bir bağ olduğu düşünülmektedir. Uluslararası spor organizasyonlarında görev alan gönüllülerin motivasyon faktörleri ile serbest zaman doyum düzeylerinin incelenmesi amacıyla yapılan bu çalışmanın literatüre önemli katkıları olacağı düşünülmektedir. Çalışmanın teorik dayanağını oluşturan motivasyon kuramı ve serbest zaman yaklaşımı ile ilişkisi de düşünüldüğünde; gönüllü katılımcıların bir ciddi serbest zaman etkinliği olarak katıldığı gönüllülük faaliyetlerinin anlaşılmasının, gönüllü katılımcılar ve uluslararası spor organizasyonları açısından bu çalışma ile birlikte çok yönlü fayda ve katkılar sağlayabileceği düşünülebilir. Bu katkılar organizasyonlar ve toplumlar açısından, ülkemizdeki spor gönüllüsü katılımcıların motivasyon faktörleri ile serbest zamanlarındaki doyum düzeylerinin ve bu kavramlar arasındaki ilişkinin bilinmesi sonucunda, organizasyon koşullarında gönüllü katılımcılar adına ilgi çekici, iyileştirici, kolaylaştırıcı ve sistemli adımların atılması ile mümkün olabilir. Bununla birlikte toplum ve organizasyonlar için büyük önem arz eden spor gönüllüleri açısından ise bu iyileştirici ve kolaylaştırıcı sistemler ile bir süreklilik ya da devamlılık durumu oluşturacağı ya da daha fazla bireyin sporda gönüllü olabilmesine katkı sağlayacağı düşünülebilir. Serbest zaman kavramı açısından ise, bireylerinin günlük yaşamı için yeniden yaratılma, yenilenme ve motive olma duygularının kazanım olabileceği, kaliteli bir serbest zaman etkinliği içerisinde bulunmanın, iyi olma halini arttırarak bireylerden, grup ve topluluklara yayılabilecek pozitif faydalar doğurabileceği düşünülebilir.

Çıkar Çatışması: Çalışma kapsamında herhangi bir kişisel ve finansal çıkar çatışması bulunmamaktadır.

Araştırmacıların Katkı Oranı Beyanı: Araştırma Dizaynı- BE; PGG, İstatistik analiz- BE, Makalenin hazırlanması- BE; PGG: 1. ve 2. yazarlar tarafından gerçekleştirilmiştir. Verilerin Toplanması- BE: 1. yazar tarafından gerçekleştirilmiştir.

\section{Etik Kurul İzni ile ilgili Bilgiler}

Kurul Adı: Manisa Celal Bayar Üniversitesi Sosyal ve Beşeri Bilimler Bilimsel Araştırma ve Yayın Etiği Kurulu

Tarih: 02.01.2020

Sayı/Karar No: 050.01.04 
Er, B. ve Güzel Gürbüz, P. (2021). Uluslararası spor organizasyonlarında gönüllü motivasyonu ile serbest zaman doyum düzeyi arasındaki ilişkinin incelenmesi. Spor Bilimleri Araştırmaları Dergisi, 6(1), 152-172.

\section{KAYNAKLAR}

Adams, N., Little, T. D. \& Ryan, R. M. (2017). Self-determination theory. In Development of self-determination through the life-course (pp. 47-54). Dordrecht: Springer.

Ardahan, F. ve Lapa, T. Y. (2010). Üniversite öğrencilerinin serbest zaman tatmin düzeylerinin cinsiyete ve gelire göre incelenmesi. Spor Bilimleri Dergisi, 21(4), 129-136.

Bang, H. \& Chelladurai, P. (2009). Development and validation of the volunteer motivations scale for international sporting events (VMS-ISE). International Journal of Sport Management and Marketing, 6(4), 332-350. https://doi.org/10.1504/IJSMM.2009.030064

Bang, H. \& Ross, S. D. (2009). Volunteer motivation and satisfaction. Journal of Venue and Event Management, 1(1), 61-77.

Bang, H., Alexandris, K. \& Ross, S. D. (2009). Validation of the revised volunteer motivations scale for international sporting events (VMS-ISE) at the Athens 2004 Olympic Games. Event Management, 12(34), 119-131.

Beard, J. G. \& Ragheb, M. G. (1980). Measuring leisure satisfaction. Journal of Leisure Research, 12(1), 20-33. https://doi.org/10.1080/00222216.1980.11969416

Berber, S. ve Terekli, M. S. (2019). Spor etkinliklerinde gönüllü yönetimi ve motivasyonu. GSI Journals Serie A: Advancements in Tourism Recreation and Sports Sciences, 2(1), 95-121. https://doi.org/10.5281/zenodo.3360339.

Broughton, K. \& Beggs, B. A. (2007). Leisure satisfaction of older adults. Activities, Adaptation \& Aging, 31(1), 1-18. https://doi.org/10.1300/J016v31n01_01.

Brown, B. A. \& Frankel, B. G. (1993). Activity through the years: Leisure, leisure satisfaction, and life satisfaction. Sociology of Sport Journal, 10(1), 1-17. https://doi.org/10.1123/ssj.10.1.1

Cengiz, R. ve Yaşartürk, F. (2020). Fitness katılımcılarının spor salonlarındaki hizmet kalitesi ve serbest zaman doyum düzeyleri arasındaki ilişkinin incelenmesi. Uluslararası Güncel Eğitim Araştırmaları Dergisi, 6(1), 48-62.

Chapman, J. G. \& Morley, R. (1999). Collegiate service-learning: Motives underlying volunteerism and satisfaction with volunteer service. Journal of Prevention \& Intervention in the Community, 18(1-2), 1933. https://doi.org/10.1300/J005v18n01_03.

Cheng, H.P. (2010). Serious leisure, leisure satisfaction and gardening by older adults. Doctoral dissertation, University of Queensland, Brisbane, Australia.

Clary, E. G., Snyder, M., Ridge, R. D., Copeland, J., Stukas, A. A., Haugen, J. \& Miene, P. (1998). Understanding and assessing the motivations of volunteers: a functional approach. Journal of personality and social psychology, 74(6), 1516-1530. https://doi.org/10.1037/0022-3514.74.6.1516

Cnaan, R. A. \& Goldberg-Glen, R. S. (1991). Measuring motivation to volunteer in human services. The Journal of Applied Behavioral Science, 27(3), 269-284. https://doi.org/10.1177/0021886391273003.

Cuskelly, G., Harrington, M. \& Stebbins, R. A. (2002). Changing levels of organizational commitment amongst sport volunteers: A serious leisure approach. Leisure/Loisir, 27(3-4), 191-212. https://doi.org/10.1080/14927713.2002.9651303.

Cuskelly, G., Hoye, R. \& Auld, C. (2006). Working with volunteers in sport: Theory and practice. London: Routledge.

Çankaya, Z. C. (2016). Özerklik desteği, temel psikolojik ihtiyaçların doyumu ve öznel iyi olma: Öz-belirleme kuramı. Türk Psikolojik Danışma ve Rehberlik Dergisi, 4(31), 23-31.

Çelik, G. (2011). Kamu kuruluşlarında çalışan engelli bireylerin serbest zaman engellerinin ve tatmin düzeylerinin incelenmesi (Antalya merkez örneği). Yayımlanmamış Yüksek Lisans Tezi, Akdeniz Üniversitesi Sosyal Bilimler Enstitüsü, Spor Yöneticiliği Anabilim Dalı, Antalya. 
Er, B. ve Güzel Gürbüz, P. (2021). Uluslararası spor organizasyonlarında gönüllü motivasyonu ile serbest zaman doyum düzeyi arasındaki ilişkinin incelenmesi. Spor Bilimleri Araştırmaları Dergisi, 6(1), 152-172.

Dawson, P. \& Downward, P. (2013). The relationship between participation in sport and sport volunteering: An economic analysis. International Journal of Sports Finance, 8(1), 75-92.

Deci, E. L. \& Ryan, R. M. (2000). The" what" and" why" of goal pursuits: Human needs and the self-determination of behavior. Psychological Inquiry, 11(4), 227-268. https://doi.org/10.1207/S15327965PLI1104_01.

Downward, P. M. \& Ralston, R. (2006). The sports development potential of sports event volunteering: Insights from the XVII Manchester Commonwealth Games. European Sport Management Quarterly, 6(4), 333 351. https://doi.org/10.1080/16184740601154474.

Downward, P., Hallmann, K. \& Rasciute, S. (2020). Volunteering and leisure activity in the United Kingdom: A longitudinal analysis of males and females. Nonprofit and Voluntary Sector Quarterly, 49(4), 757-775. https://doi.org/10.1177/0899764020901815

Doğan, M., Elçi, G. ve Gürbüz, B. (2019). Serbest zaman doyumu, serbest zamanda sıkılma algısı ve iş tatmini ilişkisi: Akademisyenler üzerine bir araştırma. Spormetre Beden Eğitimi ve Spor Bilimleri Dergisi, 17(1), 154-164. https://doi.org/10.33689/spormetre.521555

Farrell, J. M., Johnston, M. E. \& Twynam, G. D. (1998). Volunteer motivation, satisfaction, and management at an elite sporting competition. Journal of Sport Management, 12(4), 288-300. https://doi.org/10.1123/jsm.12.4.288

Fişne, M. ve Karagöz, Y. (2016). Uluslararası spor organizasyonları için gönüllü motivasyonları ölçeği’nin Türkçe’ye uyarlanması. Spor Bilimleri Araştırmaları Dergisi, 1(1), 1-16. https://doi.org/10.25307/jssr.271322

Fletcher, T. D. \& Major, D. A. (2004). Medical students motivations to volunteer: An examination of the nature of gender differences. Sex Roles, https://doi.org/10.1023/B:SERS.0000032319.78926.54.

Gallant, K., Arai, S. \& Smale, B. (2013). Serious leisure as an avenue for nurturing community. Leisure Sciences, 35(4), 320-336. https://doi.org/10.1080/01490400.2013.797324.

Getz, D. (2008). Event tourism: Definition, evolution, and research. Tourism Management, 29(3), 403-428. https://doi.org/10.1016/j.tourman.2007.07.017.

Giannoulakis, C., Wang, C.-H. \& Gray, D. (2008). Measuring volunteer motivation in mega sporting events. Event Management, 11(4), 191-200. https://doi.org/10.3727/152599508785899884

Gökçe, H. ve Orhan, K. (2011). Serbest zaman doyum ölçeği’nin Türkçe geçerlilik güvenirlik çalışması. Spor Bilimleri Dergisi, 22(4), 139-145.

Güntert, S. T., Strubel, I. T., Kals, E. \& Wehner, T. (2016). The quality of volunteers motives: Integrating the functional approach and self-determination theory. The Journal of Social Psychology, 156(3), 310-327. https://doi.org/10.1080/00224545.2015.1135864.

Karlı, Ü., Polat, E., Yılmaz, B. ve Koçak, S. (2008). Serbest zaman tatmin ölçeği'nin (SZTÖ-Uzun Versiyon) geçerlilik ve güvenilirlik çalışması. Spor Bilimleri Dergisi, 19(2), 80-91.

Kaufman, J. E. (1988). Leisure and anxiety: A study of retirees. Activities, Adaptation \& Aging, 11(1), 1-10. https://doi.org/10.1300/J016v11n01_01.

Khoo, S. \& Engelhorn, R. (2007). Volunteer motivations for the Malaysian paralympiad. Tourism and Hospitality Planning \& Development, 4(3), 159- 167. https://doi.org/10.1080/14790530701733413.

Kim, Y. M. \& Han, H. W. (2005). The influence of enjoyment of dance sports on leisure flow experience and leisure satisfaction. Korean Journal of Physical Education, 44(6), 193-202.

Lapa, T. Y. (2013). Life satisfaction, leisure satisfaction and perceived freedom of park recreation participants. Procedia-Social and Behavioral Sciences, 93, 1985- 1993. https://doi: 10.1016/j.sbspro.2013.10.153 
Er, B. ve Güzel Gürbüz, P. (2021). Uluslararası spor organizasyonlarında gönüllü motivasyonu ile serbest zaman doyum düzeyi arasındaki ilişkinin incelenmesi. Spor Bilimleri Araştırmaları Dergisi, 6(1), 152-172.

Lee, C. K., Reisinger, Y., Kim, M. J. \& Yoon, S. M. (2014). The influence of volunteer motivation on satisfaction, attitudes, and support for a megaevent. International Journal of Hospitality Management, 40, 37-48. https://doi.org/10.1016/j.ijhm.2014.03.003

Liu, H. (2014). Personality, leisure satisfaction, and subjective well-being of serious leisure participants. Social Behavior and Personality: An International Journal,42(7), 1117-1125. https://doi.org/10.2224/sbp.2014.42.7.1117

Liu, H. \& Yu, B. (2015). Serious leisure, leisure satisfaction and subjective well-being of Chinese university students. Social Indicators Research, 122(1), 159-174. https://doi.org/10.1007/s11205-014-0687-6.

Lockstone-Binney, L., Holmes, K., Smith, K. \& Baum, T. (2010). Volunteers and volunteering in leisure: Social science perspectives. Leisure Studies, 29(4), 435-455. https://doi.org/10.1080/02614367.2010.527357.

Lu, L. \& Argyle, M. (1994). Leisure satisfaction and happiness as a function of leisure activity. Gaoxiong yi xue ke xue za zhi= The Kaohsiung Journal of Medical Sciences, 10(2), 89-96.

Moon, T. Y. \& Heo, C. U. (2011). Impact of participation in sport for all on leisure satisfaction, psychological wellbeing and subjective wellbeing. Journal of the Korea Academia-Industrial Cooperation Society, 12(9), 3984-3993. http://dx.doi.org/10.5762/KAIS.2011.12.9.3984

Mouratidis, K. (2019). Built environment and leisure satisfaction: The role of commute time, social interaction, and active travel. Journal of Transport Geography, 80, 102491. https://doi.org/10.1016/j.jtrangeo.2019.102491

Oostlander, J., Güntert, S. T., Van Schie, S. \& Wehner, T. (2014). Leadership and volunteer motivation: A study using self-determination theory. Nonprofit and Voluntary Sector Quarterly,43(5), 869-889. https://doi.org/10.1177/0899764013485158.

Parker, S. R. (1997). Volunteering — altruism, markets, causes and leisure. World Leisure \& Recreation, 39(3), 4-5. https://doi.org/10.1080/10261133.1997.9674070.

Pauline, G. \& Pauline, J. S. (2009). Volunteer motivation and demographic influences at a professional tennis event. Team Performance Management: An International Journal, 15(3/4), 172-184. https://doi.org/10.1108/13527590910964946.

Riddick, C. C. (1986). Leisure satisfaction precursors. Journal of Leisure research, 18(4), 259-265. https://doi.org/10.1080/00222216.1986.11969664.

Ringuet, C. (2012). Volunteers in sport: Motivations and commitment to volunteer roles. Aspetar Sports Med J, $1,154-161$.

Ringuet-Riot, C., Cuskelly, G., Auld, C. \& Zakus, D. H. (2014). Volunteer roles, involvement and commitment in voluntary sport organizations: Evidence of core and peripheral volunteers. Sport in Society, 17(1), 116133. https://doi.org/10.1080/17430437.2013.828902.

Ryan, R. M. ve Deci, E. L. (2000). Self-determination theory and the facilitation of intrinsic motivation, social development, and well-being. American Psychologist, 55(1), 68-78. DOI: 10.1037110003-066X.55.1.68

Ryan, R. (2009). Self determination theory and well being. Social Psychology, 84(822), 848

Sayım, F. (2015). Sosyal bilimlerde araştırma ve tez yazım yöntemleri. Ankara: Seçkin.

Shin, K. \& You, S. (2013). Leisure type, leisure satisfaction and adolescents' psychological wellbeing. Journal of Pacific Rim Psychology, 7(2), 53-62. https://doi.org/10.1017/prp.2013.6.

Solberg, H. A. (2003). Major sporting events: Assessing the value of volunteers' work. Managing Leisure, 8(1), 17-27. https://doi.org/10.1080/1360671032000075216.

Stebbins, R. A. (1996). Volunteering: A serious leisure perspective. Nonprofit and voluntary sector quarterly, 25(2), 211-224. https://doi.org/10.1177/0899764096252005. 
Er, B. ve Güzel Gürbüz, P. (2021). Uluslararası spor organizasyonlarında gönüllü motivasyonu ile serbest zaman doyum düzeyi arasındaki ilişkinin incelenmesi. Spor Bilimleri Araştırmaları Dergisi, 6(1), 152-172.

Stebbins, R. A. (2005). Project-based leisure: theoretical neglect of a common use of free time. Leisure Studies, 24(1), 1-11. https://doi.org/10.1080/0261436042000180832.

Stebbins, R. A. (2006). Serious leisure. In A handbook of leisure studies (pp. 448-456). London: Palgrave Macmillan.

Stebbins, R. A. (2007). Serious leisure: A perspective for our time (Vol. 95). New Brunswick, New Jersey: Transaction Publishers.

Stebbins, R. (2014). Careers in serious leisure: From dabbler to devotee in search of fulfilment. London: Palgrave Macmillan.

Stebbins, R. A. (2016). Leisure and positive psychology: Linking activities with positiveness. London: Palgrave Macmillan.

Taylor, T., Doherty, A. \& McGraw, P. (2008). Managing people in sport organizations: A strategic human resource management perspective. New York: Routledge.

Tian, H. B., Qiu, Y. J., Lin, Y. Q., Zhou, W. T. \& Fan, C. Y. (2020). The Role of Leisure Satisfaction in Serious Leisure and Subjective Well-Being: Evidence from Chinese Marathon Runners. Frontiers in Psychology, 11, 581908, 1-10. https:// doi: 10.3389/fpsyg.2020.581908.

Twynam, G. D., Farrell, J. M. \& Johnston, M. E. (2002). Leisure and volunteer motivation at a special sporting event. Leisure/Loisir, 27(3-4), 363-377. https://doi.org/10.1080/14927713.2002.9651310.

Ural, A. ve Kılıç, İ. (2018). Bilimsel araştırma süreci ve spss ile veri analizi. Ankara: Detay Yayıncılık.

Van Til, J. (1988). Mapping the third sector: Voluntarism in a changing social economy. New York: The Foundation Center.

Wang, C. \& Yu, L. (2015). Managing student volunteers for mega events: motivation and psychological contract as predictors of sustained volunteerism. Asia Pacific Journal of Tourism Research, 20(3), 338-357. https://doi.org/10.1080/10941665.2014.889027.

Widjaja, E. (2010). Motivation behind volunteerism CMC senior theses. Paper 4. http://scholarship.claremont.edu/cmc_theses/4.

Wu, Y., Li, C. \& Khoo, S. (2016). Predicting future volunteering intentions through a self-determination theory perspective. VOLUNTAS: International Journal of Voluntary and Nonprofit Organizations, 27(3), 12661279. https://DOI 10.1007/s11266-015-9570-6

Bu eser Creative Commons Atıf-Gayri Ticari 4.0 Uluslararası Lisansı ile lisanslanmıştır. 